\title{
Preparation of New Physics Teachers in the Light of Goals of Physics Education
}

\section{Peter Demkanin}

Comenius University in Bratislava, Faculty of Mathematics, Physics and Informatics, Bratislava, Slovakia,demkanin@fmph.uniba.sk

\begin{abstract}
In some of our previous articles, we have analysed and discussed the goals of physics education at secondary schools and some aspects of physics education at the secondary school level. In this contribution, we proceed with bringing our experience with the preparation of new physics teachers at Comenius University in Bratislava. We discuss the theoretical background we used as a base for preparing the curriculum for university students future physics teachers, and we highlight some aspects of their preparation. Primarily, we focus on the development of abilities to scaffold the learning of their future secondary schools' students. In details, we describe the ways we try to improve the abilities of our students to scaffold their future secondary schools' students in concept formation, process skills development, in planning and processing inquiry, ability to scaffold practical work with literature. As a vast majority of our graduates will teach their secondary school students in the Slovak language, which is a language used by a small number of people $(5 \mathrm{mils})$. So we discuss also some specifics related to physics textbooks for secondary schools in Slovak language, university textbooks available in Slovak language and ability of our university studentsfuture physics teachers to work with sources written in English. At the conclusion, we propose some possible improvements, hopefully, inspiring also for preparation of physics teachers for other educational systems.
\end{abstract}

Keywords: physics teacher, pre-service teacher, teacher preparation, physics education. 


\section{Introduction}

Preparation of physics teachers at Comenius University in Bratislava has a long history, which, of course, has some influence on the present state. In this contribution, we discuss the present state and some innovations we are applying these years.

Future physics teachers are prepared in combination with another subject, most of them with mathematics, and for higher and lower secondary education. Based on Shulman's domains of teacher knowledge (Shulman 1987), transformative model of teachers preparation is preferred, integrative is tried to avoid. The courses are focused mainly on pedagogical content knowledge (PCK), subject matter knowledge (bachelor physics course, adapted for future teachers) and educational psychology. Some time is also devoted to curricular knowledge (oriented on Slovak national curriculum and often compared with International Baccalaureate curriculum); knowledge of learners (as a part of educational psychology); knowledge of educational contexts and knowledge of philosophical and historical goals of education.

Even if our university preparation of physics teacher is based on upper-mentioned decisions, we can say that the present state of physics teachers preparation in Slovakia can be described as unsettled, quite changing. A similar situation can also be seen in many other educational systems. Even if the author of this contribution is also the main author of the national physics curriculum, which was formulated more than ten years ago, it can be said that it needs reform. Some schools in Slovakia try to adopt some aspects of physics education from other educational systems. It must be mentioned that most of such attempts do not bring internally consistent sights.

In the world, we can see some innovation paths. Some systems emphasis content of physics education and utilise instructional methods, cognitive constructivism methods. Some of the others put the accent on the child, pupil, on the learner. Exceptional are the ways colleagues from Finland and Norway decided to develop, where the emphasis is put on projects, complex problems inquiry, where pupils gain knowledge via complex real-life problem solutions well scaffolded by experts (including teachers). Interesting is also a relatively new approach, in which experts on practical education work in teams together with neuroscientists, psychologists and in-service teachers. Some of such groups develop the movement The Learning Science, (R.K. Sawyer, 2014) based on social constructivism. 


\section{Our focus}

Within the holistic approach, we focus on innovations in the development of teacher's competencies for:

a) Effective scaffolding of the work of pupils. Today, the concept of scaffolding is almost unknown in Slovakia, despite it is one of the basic concepts of constructivism, from the age of the introduction of constructivism. We hypothesise that this state is the result of the extreme emphasis on instructions and instructional approaches. In the traditional approach, it is tried to activate learners via instructions, but, paradoxically, the natural result is a passivity of the learner, who is not inspired to formulate her/his challenging goals, aims, is not taught to cooperate with somebody with more profound and broader knowledge and abilities. The only example of this approach in physics education in Slovakia can be mentioned, is the preparation of students for Young Physicists Tournament at some schools;

b) Management of the stages of (relatively) independent inquiry of teams of pupils;

c) Management and support of pupils in discussion ability development;

d) Formative assessment is also a topic future physics teacher used to have only mentioned, and now, within the holistic approach, it is tried to train them for it. Peer-assessment is also the aspect which should be better incorporated into the programme of teachers preparation;

e) Summative assessment, differences between formative and summative, aspects to assess within physics education;

f) Work of pupils with sources of information - our available sources in the Slovak language are limited. The work with sources of information optimised for various age levels is one of the main gaps, which we have in physics education theory now;

g) Work in the environment of computer-supported school science laboratory. We have already done much in the utilisation of sensors and data loggers. Still, we must search in the utilisation of video measurement, computer modelling (by pupils themselves), interactive animation (applets, innovated and developed by the pupils themselves);

h) Mentoring of pupils in the use of gadgets brought to school by pupils (BYOD-bring your device approach).

i) Search for a typology of physics teachers using research methodology by $\mathrm{K}$. Charmaz, grounded theory and also the model of personality by R.C. Cloninger, and here we are just at the starting point. 


\section{Textbook for preparation of new physics teachers}

Last year we finalised a textbook for our students - university students of physics education in combination wot hither school subjects (Demkanin, 2018). The textbook, Physics education for Pre-Service and In-Service Physics Teachers, is now available in Slovak only. Let us present some of its features.

In the preface we say: Physics teacher today at a secondary school is facing demanding task - to work with children, adolescents, with their parents, to fulfil goals of physics education, clearly present her/his requirements towards pupils and consistently demand to meet them by them, to activate pupils for awareness of their process of learning, to learn pupils to observe, measure, make experiments, inquire, and lead them to thinking, to utilisation of their own previous knowledge. Besides investigating nature, physics teacher also teaches how to use some technologies. In these two sentences are presented eight chapters of this book. Next chapters are devoted to informal and unformal physics education, concepts formation and concept transformation, to science projects at schools and assessment. In conclusion, some historical view and some vision of the future is offered. To present this textbook in more details, let us discuss the chapters and our goals related to these chapters.

In the introduction, it is stressed the central question of the book - What it is about the quality of physics education? Moreover, we discuss the main dimensions of a teacher knowledge, abilities and relations. In one table, we present the assumptions related to the physics content, the list of topics the university student of magister level study, future physics teacher, should know to be able to use this textbook. In the second table, we present a list of some psychologists. We used the list of the most cited psychologists in 20 . Century, where are such names as B.F.Skninner (behaviourism and programmed learning), J. Piaget (cognitive development), S. Freud (psychoanalysis), A. Bandura (social psychology), L. Festinger (social psychology, mental discomfort), C.R. Rogers (humanistic psychology), S. Schachter (theory of emotions), N. Miller (experimental behaviourist), E. Thorndike (educational psychologist), A. Maslow (hierarchy of needs), and some others. Our aim here is to focus attention on the needs to base the physics education on facts, on the results of systematic research (including the research of psychologists). Of course, we do not focus the attention of our students - future physics teachers, on the in-depth study of all parts of general psychology. Later in the book, we use mainly the results of The Learning Science movement presented by-R.K. Sawyer. In this introduction, we also present a list of some terms with short descriptions, terms like knowledge, information, concept, phenomenon, the strategy of education, teaching style, experiment, variable in an experiment, observation. 
In chapter one of the textbook, the attention of the students is focused on the topics of this textbook, and we try to demarcate, define the topics of this textbook. We are trying to present The transformative approach is presented; the teacher can have in one domain topics like ways to focus the attention of learners, personality model, working with pupils, which disobey, transform units of physical quantities, working with graphs of physical dependence. The students here solve problems like:

A flute emits the sound of frequency $440 \mathrm{~Hz}$. Determine the wavelength of this sound and the length of the flute closed at one end, which emits this sound.

Propose an experiment to measure the speed of sound in a school laboratory.

Discuss how the teaching of physics and higher secondary school can help to raise the use of public transport in the horizon of 10 years.

The problems should be not only solved/answered, but the reason we use such problems within physics education should also be discussed.

One of the next tasks is to discuss the interrelation between secondary level school derivation of Bernoulli's equation (from the conservation of energy principle) and the character development. We use here the model of the personality of R.C Cloninger and discuss the development of three traits of character - Self-Directedness, Cooperativeness and Self-Transcendence. The students should in this chapter also discuss, what to do, if a secondary school student refuses to deal with the Bernoulli's equation, giving the reason, that she is planning to study Economics at University and that she will not need to understand the Bernoulli's equation derivation. We use here some parts of Adler's psychology.

Chapter 2 of the textbook and also the second lesson is focused on the goals of physics education. 3-level primary taxonomy of goals formulated previously (Demkanin, 2013) is used. Then we go to Big Ideas formulated by W. Harlen with her team (2010), (2015). With these Big Ideas, students also work on other parts of the textbook, especially in the chapter devoted to the concept formation. The easy to use the formulation of goals is adapted from the International Baccalaureate Diploma Programme, which is followed by some school physics examples, in which the students should discuss the goals, which are fulfilled by these examples. The most favourite is the last task of this chapter - to suggest a method (way, process) to fulfil a specific goal: To present, that physics is a very demanding science discipline, no one, except the physics teacher, can understand.

In chapter 3, we deal with the role/position of the pupil and the role/position of the teacher within formal physics education. Shortly we list some of the school of learning (J. Bruner, T. Luckmann, B.F Skinner, A. Bandura, R. Steiner, M. Montessori). After this short introduction we highlight, that "learning is making sense of new experience by learners in 
collaboration with others" (Harlen, 2006) and this idea is applied in some contexts filament bulb (hot and lighting), working with a textbook, watching a movie (Harry Potter), barking dog, cooling cup of tea, cooling cup of tea with exponential function used, radioactive decay. The discussion on the role of the teacher is based on the work of $\mathrm{W}$. Harlen (2006), and one of the examples brings very poorly formulated instruction for pupils. The student should identify bad aspects of the instructions and try to re-work to be usable. In this chapter, our students also find quite a large part focused on scaffolding, mainly based on the work of Reiser and Tabak (2014). The last part of this chapter is focused on the conversation in the work of teacher and in detail is presented exploratory talk (Mercer, 2000).

\section{Conclusion, near-future development}

The book discussed in this contribution was met by the University students as well as by the in-service physics teachers very well. There was a gap in this field, the previous book on the similar topic has been published in the Slovak language in 1988, and there was made, and still is made profound changes in physics education. It can be seen, that the sight of the students on the physics education via this book is changing and it is met the goal not to teach as I was taught, base my teaching on the results of relevant research.

In this contribution, some aspects of future physics teachers at Comenius University and also the first three chapters of the new textbook Physics Education is presented. The intention was to contribute to a discussion or to initiate a discussion on the topic of physics teachers' education. All ideas are welcomed via email, future years of this conference or via ResearchGate.

\section{Acknowledgements}

This work has been supported by Scientific Grant Agency of the Ministry of Education under the contract VEGA 1/0273/19, Tutoring and Scaffolding in the Preparation of PreService Physics Teachers.

\section{References}

Demkanin, P. (2018). Didaktika fyziky pre študentov magisterského štúdia a učitel’ov v praxi (Physics Ecucation). Comenius University, Bratislava. 
Demkanin, P. (2013). Preparation of new physics teachers from various perspectives. Journal of Baltic Science Education, 12.

Demkanin, P., Velanová, M. (2015). Klúčové tézy obsahu prírodovedného vzdelávania ako kritérium výberu obsahu pre prírodovedné kurikulum. In: Held, L. (editor) Východiská prípravy prírodovedného kurikula pre základnú školu 2020 II. Trnava: Trnavská univerzita,

Harlen, W. (2006). Teaching, Learning and Assessing Science 5-12. London: SAGE.

Harlen, W. (2010). Principles and big ideas of science education. Herts: Association for Science Education.

Harlen, W. (2015). Working with Big Ideas of Science Education. Trieste: Science Education Programme of IAP.

Magnusson, S., Krajcik, J., \& Borko, H. (1999). Nature, sources and development of Pedagogical Content Knowledge for Science Teaching. In J. Gress-Newsome, \& N. Lederman, Examining Pedagogical Content Knowledge (p. 95-132). Amsterdam: Kluwer Academic Publishers

Mercer, N. (2000). Words and Minds: how to use language to think together. London: Routlege

Reiser, B., \& Tabak, I. (2014). Scaffolding. In R. Sawyer, The Cambridge Handbook of The Learning Sciences (p. 44-62). Cambridge University Press.

Sawyer, R. K. (2014). The Cambridge Handbook of The Learning Sciences. Cambridge University Press.

Shulman, L. (1987). Knowledge and Teaching. Harward Educational Review, 1-22. 